\title{
Conf-941075--?
}

UCRL-JC-116429

PREPRINT

\section{The Importance of Thermal Loading Conditions to Waste Package Performance at Yucca Mountain}

\author{
Thomas A. Buscheck \\ John J. Nitao
}
This paper was prepared for submittal to the Materials Research Society XVIII International Symposium on the Scientific Basis for Nuclear Waste Management Kyoto, Japan
October 23-27, 1994

\section{October 1994}

This is a preprint of a paper intended for publication in a journal or proceedings. Since changes may be made before publication, this preprint is made available with the understanding that it will not be cited or reproduced without the permission of the author.

\section{DISCLAIMER}

This report was prepared as an account of work sponsored by an agency of the United States Government. Neither the United States Government nor any agency thereof, nor any of their employees, makes any warranty, express or implied, or assumes any legal liability or responsibility for the accuracy, completeness, or usefulness of any information, apparatus, product, or process disclosed, or represents that its use would not infringe privately owned rights. Reference herein to any specific commercial product, process, or service by trade name, trademark, manufacturer, or otherwise does not necessarily constitute or imply its endorsement, recommendation, or favoring by the United States Government or any agency thereof. The views and opinions of authors expressed herein do not necessarily state or reflect those of the United States Government or any agency thereof. 


\section{DISCLAIMER}

This document was prepared as an account of work sponsored by an agency of the United States Government. Neither the United States Government nor the University of California nor any of their employees, makes any warranty, express or implied, or assumes any legal liability or responsibility for the accuracy, completeness, or usefulness of any information, apparatus, product, or process disclosed, or represents that its use would not infringe privately owned rights. Reference herein to any specific commercial product, process, or service by trade name, trademark, manufacturer, or otherwise, does not necessarily constitute or imply its endorsement, recommendation, or favoring by the United States Government or the University of California. The views and opinions of authors expressed herein do not necessarily state or reflect those of the United States Government or the University of California, and shall not be used for advertising or product endorsement purposes. 


\section{DISCLAIMER}

Portions of this document may be illegible in electronic image products. Images are produced from the best available original document. 


\title{
The Importance of Thermal Loading Conditions to Waste Package Performance at Yucca Mountain
}

\author{
Thomas A. Buscheck \\ John J. Nitao
}

Manuscript date: October 1994

Earth Sciences Division, L-206,

Lawrence Livermore National Laboratory,

P.O. Box 808, Livermore, CA 94551 


\title{
The Importance of Thermal Loading Conditions to Waste Package Performance at Yucca Mountain
}

\begin{abstract}
Temperature and relative humidity are primary environmental factors affecting waste package corrosion rates for the potential repository in the unsaturated zone at Yucca Mountain, Nevada. Under ambient conditions, the repository environment is quite humid. If relative humidity is low enough $(<70 \%)$, corrosion will be minimal. Under humid conditions, corrosion is reduced if the temperature is low $\left(<60^{\circ} \mathrm{C}\right)$. Using the V-TOUGH code, we model thermo-hydrological flow to investigate the effect of repository heat on temperature and relative humidity in the repository for a wide range of thermal loads. These calculations indicate that repository heat may substantially reduce relative humidity on the waste package, over hundreds of years for low thermal loads and over tens of thousands of years for high thermal loads. Temperatures associated with a given relative humidity decrease with increasing thermal load. Thermal load distributions can be optimized to yield a more uniform reduction in relative humidity during the boiling period.
\end{abstract}

\section{Introduction}

The U.S. Department of Energy is investigating the suitability of the unsaturated zone (UZ) at Yucca Mountain, Nevada, as a potential site for a high-level nuclear waste repository. To safely and permanently store waste, the repository system must limit gas- or liquid-phase transport of radionuclides to the accessible environment. As regards waste package (WP) performance, the repository system must meet the regulatory requirements for substantially complete containment (SCC) and controlled release from the engineered barrier system (EBS). A major concern is how water contacts a WP, thereby affecting its integrity and (if containment is breached) affecting radionuclide dissolution and transport to the water table. The degradational mechanisms of greatest concern for WP integrity, such as stress and pitting corrosion or microbial attack, require the presence of liquid water. The rates for many of these mechanisms are increased under warm, humid conditions.

The two primary modes of water contact on the WP are (1) advective liquid flow and (2) condensation of water vapor on the WP. The critical factors for the second mode are the relative humidity $R H$ and temperature $T$ on the WP. Regardless of whether mobile liquid water is present, ambient $R H$ at the repository horizon is 98 to 99\%. If the ambient $R H$ could be sufficiently reduced, WP corrosion rates would be minimal [1]. Moreover, even for breached WPs, waste-form dissolution is minimal if no mobile liquid water is present. There are two ways to reduce $R H$ on the WP:

1. Drive a large fraction of the initial pore water from the vicinity of the WPs.

2. Maintain a steep enough temperature gradient away from the WP.

The primary means of reducing the pore water are repository-heat-generated drying and ventilation. To reduce $R H$ to $70 \%$, the liquid saturation $S_{1}$ (the fraction of the pore space filled with liquid water) must be reduced to less than 20\%. An areal mass loading (AML, expressed in metric tons of uranium per acre, MTU/acre) that does not drive repository temperatures well above the boiling point will only slightly reduce average $R H$ conditions. Figure 1, based on a repository-scale model [2], summarizes the peak temperature and minimum $R H$ at the center and outer edge of the repository for a wide range of AMLs. Figure 2, based on a drift-scale model [2], summarizes conditions on the WP for the same range of AMLs.

Fluid flow in the UZ at Yucca Mountain involves liquid- and gas-phase flow through the fractures and the rock matrix. Except for regions with a perched water table or during transient recharge episodes, capillary forces cause most fractures to be drained of liquid water. Matrix permeability at Yucca Mountain 
is extremely low, so matrix flow is of less concern than fracture flow for water contact by advective liquid flow and for radionuclide transport. This water may arise from three origins:

1. Natural infiltration of rainfall and snowmelt.

2. Condensate generated under boiling conditions.

3. Condensate generated under sub-boiling conditions. The first source arises from the ambient system; the second and third are generated by radioactive decay heat, primarily from spent nuclear fuel (SNF). Heatdriven, buoyant vapor flow and the binary diffusion of water vapor and air may play important roles in condensate generation [3]. A heterogeneous distribution of bulk permeability $k_{\mathrm{b}}$ can influence vapor and condensate flow, under both boiling and sub-boiling conditions. Of particular concern are $k_{\mathrm{b}}$ distributions that promote the focusing of condensate flow, which could cause water to drip onto WPs, even if average behavior would indicate otherwise [3].

Repository heat can result in regions of dry-out and condensate buildup in the UZ. These effects, along with temperature changes, can alter the hydrological, geochemical, and geomechanical properties that influence fluid flow and radionuclide transport.

Repository heat also drives buoyant, liquid-phase convection in the saturated zone (SZ). This convection is likely to dominate radionuclide transport in the SZ for tens of thousands of years [4]. A $k_{\mathrm{b}}$ distribution that facilitates deep convective mixing would result in more dilution of radionuclides in the SZ than a stagnant water table.

This paper focuses on the effect of repository-heatdriven gas- and liquid-phase flow on $T$ and $R H$ in the repository. Some of the results of this work have been applied to a WP performance study described elsewhere in these proceedings [1].

\section{Numerical Models and Assumptions}

All model calculations were carried out using the V-TOUGH code [5,6], which models the coupled transport of water, vapor, air, and heat in fractured porous media. Our models include all major hydrostratigraphic units in the UZ; these units are

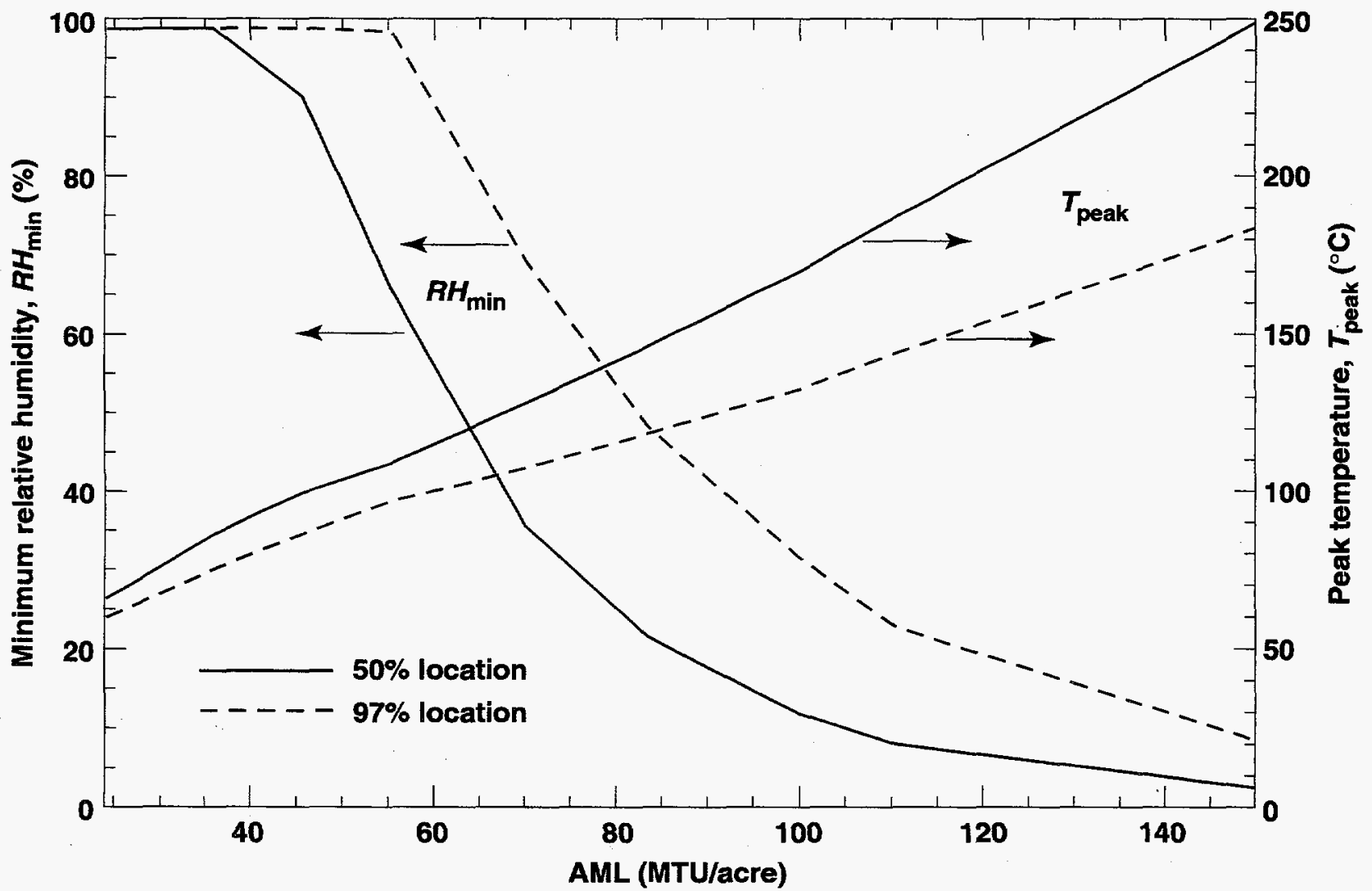

Figure 1. Minimum relative humidity and peak temperature at two repository locations as a function of AML for 22.5-yr-old SNF. These curves are based on the disk-shaped, smeared-heat-source model, so they are representative of average conditions at the respective locations in the repository. The locations are identified as the percentage of the repository area enclosed, with $0 \%$ corresponding to the repository center, and $100 \%$ corresponding to the edge. 
assumed to be horizontal and of uniform thickness [2-4]. The repository-scale model also includes the effects of heat and fluid flow in the upper $1000 \mathrm{~m}$ of the SZ. For this report, we assumed that $k_{\mathrm{b}}=280$ millidarcy, and we adopted an initial liquid saturation profile based on a net recharge flux of $0 \mathrm{~mm} / \mathrm{yr}$; however, a wide range of other conditions has also been considered [2-4].

The initial vertical distribution of temperature in the models corresponds to the nominal geothermal gradient. Atmospheric temperature, gas-phase pressure, and $R H$ are fixed at $13^{\circ} \mathrm{C}, 0.86 \mathrm{~atm}$, and $99 \%$, respectively, so that the atmosphere is in thermodynamic equilibrium with the upper UZ [3]. Under initial conditions, the model therefore allows no mass flux of water vapor between the atmosphere and upper UZ. Because actual atmospheric conditions are much less humid than assumed, the model underrepresents the diffusive loss of water vapor to the atmosphere. This neglected moisture loss may be quite substantial for high AMLs, which can steepen the temperature gradient near the ground surface by more than a factor of 50 relative to ambient conditions. The effect of this conservative assumption is offset (to some degree) by the unconservative assumption of zero net recharge flux.

The repository-scale model approximates the threedimensional system (at the scale of the mountain) using an axisymmetric $r-z$ coordinate system. Repository heat is represented by a circular, disk-shaped heat source with an area consistent with the assumed AML and with the emplacement of 63,000 MTU of SNF. The repository heat generation rate is based on a "youngest fuel first" SNF receipt scenario, with a 10 -yr cut-off for the youngest fuel [called YFF(10)]; it accounts for the emplacement of BWR WPs containing 40 assemblies per WP, and PWR WPs containing 21 assemblies per WP [2]. We considered repository areas of $2598,1755,1381$, $1139,900,755,630,570$, and 420 acres, corresponding to AMLs of 24.2, 35.9, 45.6, 55.3, 70.0, 83.4, 100.0, 110.5 , and 150.0 MTU/acre, respectively (Fig. 1).

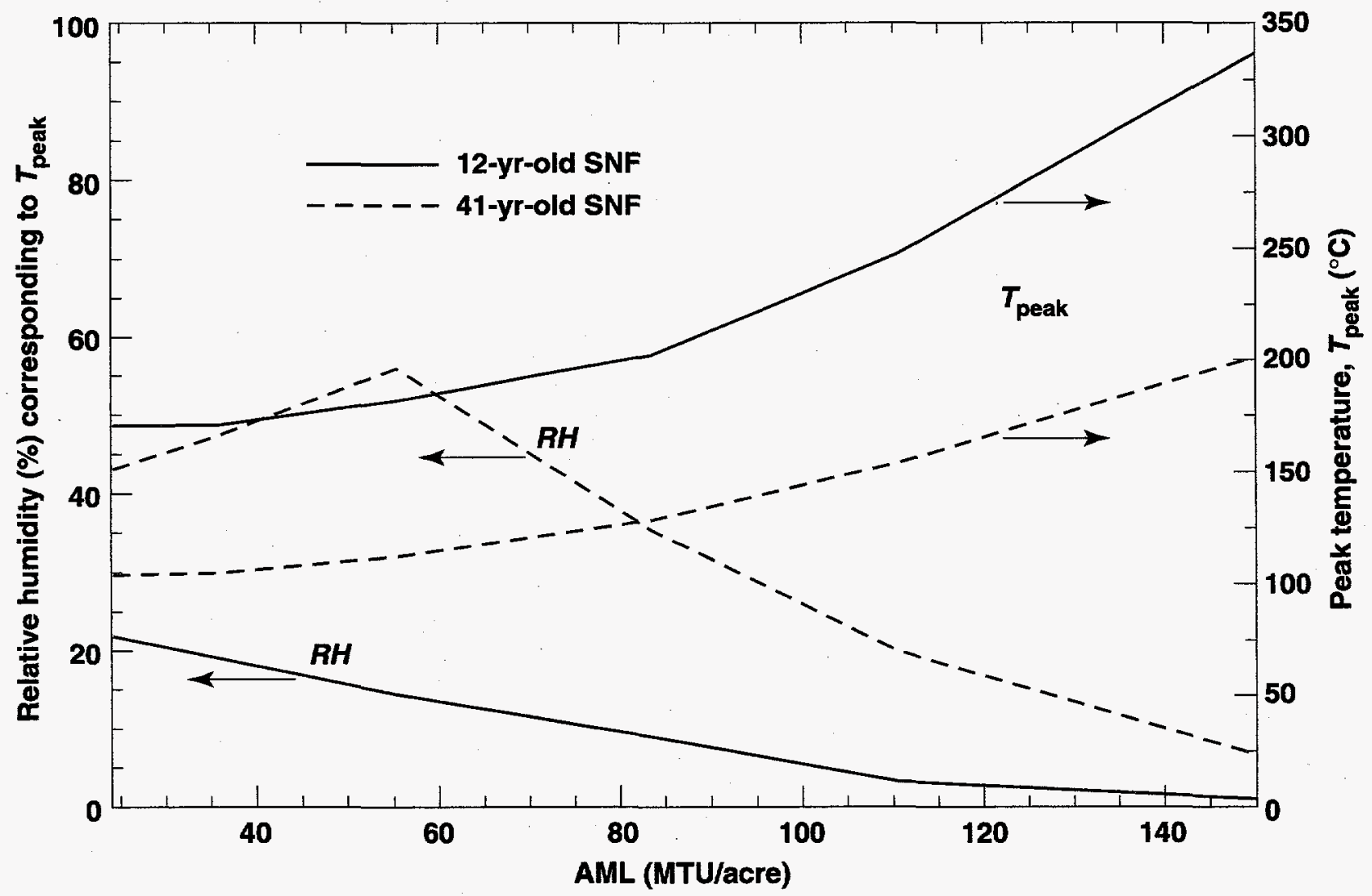

Figure 2. Peak temperature and corresponding relative humidity $R H$ on the WP as a function of AML for 12- and 41-yr-old SNF, based on the drift-scale model. The heat generation rate is for a composite of 21-PWR WPs and 40-BWR WPs with 12-m center-to-center WP spacing or for 12-PWR WPs and 21-BWR WPs with 6.86-m WP spacing. For an AML of $150 \mathrm{MTU} / \mathrm{acre}$, the WP spacings are 8.84 and $5.05 \mathrm{~m}$, respectiveiy. The center-to-center drift spacings are 99.0, 66.8, 43.4, 28.8, 21.7, and $21.7 \mathrm{~m}$ for AMLs of 24.2, 35.9, 55.3, 83.4, 110.5, and 150.0 MTU/acre, respectively. Except for 150-MTU/acre and 41-yr-old SNF cases, these cases are described in Ref. 2. 
Drift-scale behavior is represented by a twodimensional model that incorporates the geometric details of the WPs and emplacement drifts in a cross section orthogonal to the drift axis. As is apparent in Fig. 2, conditions on the WP can be significantly hotter and drier than the average repository conditions shown in Fig. 1. This is particularly true for low AMLs, or near the repository edge for higher AMLs. The drift-scale model averages the WP heat generation along the drift axis; this assumption is quite reasonable for the WP spacings listed in Fig. 2. Unlike the repository-scale model, the drift-scale model assumes a fixed-property boundary at the water table that artificially accelerates the decrease in repository temperatures after $2000 \mathrm{yr}$. Because the drift-scale model effectively assumes an infinite repository area, it is applicable to the region not affected by cooling at the repository edge. Because the primary use of this model is for the first several thousand years (when local WP conditions deviate significantly from average conditions), these two assumptions do not limit its usefulness.

\section{Discussion of Model Results}

The primary environmental factors affecting WP corrosion in the UZ at Yucca Mountain are temperature $T$ and relative humidity $R H$. Extensive experience with alloys [1] indicates that corrosion generally requires $R H>60 \%$ and that the worst conditions occur for $T>60^{\circ} \mathrm{C}$. The WP corrosion model of Stahl et al. [1] shows virtually no corrosion for $R H<70 \%$, and very low corrosion rates for $70<R H<80 \%$. The corrosion rate increases superlinearly with $R H$.

We begin by examining average $T-R H$ conditions in the repository (Table 1) for three uniform-AML cases, focusing on values of $R H$ high enough to result in significant corrosion rates. In general, we find little variation in $T$ and $R H$ for the inner $50 \%$ of the repository; we also find the following trends:

1. The duration of reduced- $R H$ conditions increases with AML.

2. The temperature associated with a given $R H$ decreases with increasing AML.

3. The duration of reduced- $R H$ conditions decreases with proximity to the edge.

4. The temperature associated with a given $R H$ increases with proximity to the edge.

The first and second of these trends level off at $110 \mathrm{MTU} / \mathrm{acre}$ for the inner $75 \%$ of the repository; for the outer $25 \%$, the trend continues for higher AMLs.

Table 2 summarizes the duration of the boiling period $t_{\mathrm{bp}}$, and $R H$ conditions at the end of the boiling period.
For the uniform-AML cases, we find the

following trends:

1. $t_{\mathrm{bp}}$ increases superlinearly with AML.

2. $R H$ at the end of the boiling period decreases with increasing AML.

3. $R H$ at the end of the boiling period increases with proximity to the repository edge.

The second of these trends also levels off at 110 MTU/acre for the inner $75 \%$ of the repository; for the outer $25 \%$, the trend continues for higher AMLs.

The worsening of $T-R H$ conditions at the repository edge is a result of two effects. While temperature decrease for the inner $75 \%$ of the repository is largely governed by one-dimensional (vertical) heat flow, heat flow becomes increasingly two-dimensional as the edge is approached, thereby increasing the cooling rate. This edge-cooling effect reduces both the magnitude and duration of the temperature buildup responsible for driving moisture away from the repository. Rewetting the inner $75 \%$ of the repository to ambient (humid) conditions is also largely a one-dimensional process, but again the process becomes increasingly twodimensional as the edge is approached. This edgerewetting effect decreases the time required to reach ambient conditions.

The edge-cooling/rewetting effects can be at least partially offset with a nonuniform AML distribution, in which the local AML increases towards the repository edge. We used an iterative process to optimize the AML distribution to yield a uniform distribution of $t_{\mathrm{bp}}$ and the duration of reduced- $R H$ conditions. In the optimized distribution, the local AML of the inner $75 \%$ of the repository is uniform; for the outer $25 \%$, the average AML is higher by $63 \%$, and the local AML increases as the edge is approached. We obtained optimized AMLs for average AMLs of $62.4,83.1,96.9,128.4$, and 174.3 MTU/acre. The 128.4-MTU/acre case (Tables 1 and 2) has an AML of 110.5 MTU/acre for the inner $75 \%$ of the repository and an average AML of $180.1 \mathrm{MTU} /$ acre for the outer $25 \%$.

Tables 1 and 2 show the benefits of optimizing the AML distribution, among which are the following:

1. A large increase in the duration of reduced- $R H$ conditions at the repository edge.

2. Lower temperatures at a given $R H$ for the outer $25 \%$ of the repository.

3. A more uniform distribution of $t_{\mathrm{bp}}$ and the duration of reduced- $R H$ conditions.

4. Lower $R H$ at the end of the boiling period for the outer $25 \%$ of the repository.

For the optimized-AML cases, the temperature associated with a given $R H$ decreases with increasing AML; the trend levels off at about $130 \mathrm{MTU} / \mathrm{acre}$. 
The primary motivations for seeking more uniform, more persistent reduced- $R H$ conditions are to meet the regulatory requirements for substantially complete containment (SCC) and controlled release from the engineered barrier system (EBS). A parameter study for a wide range of hydrological conditions indicates that

Table 1. Time to rewet to indicated relative humidity $R H$ at various repository locations, and temperature when that $R H$ is attained for 22.5-yr-old SNF. Locations are identified as the percentage of the repository area enclosed, with $0 \%$ corresponding to the repository center, and $100 \%$ corresponding to the edge.

Table 1a. AML = 55.3 MTU/acre.

\begin{tabular}{|c|c|c|c|c|c|c|c|c|}
\hline \multirow{2}{*}{$\begin{array}{c}\text { Repository } \\
\text { area enclosed } \\
(\%)\end{array}$} & \multicolumn{4}{|c|}{$\begin{array}{c}\text { Time to rewet to indicated } \\
\text { relative humidity }(\mathrm{yr})\end{array}$} & \multicolumn{4}{c|}{$\begin{array}{c}\text { Temperature when indicated } \\
\text { relative humidity is attained }\left({ }^{\circ} \mathrm{C}\right)\end{array}$} \\
\cline { 2 - 9 } & $70 \%$ & $80 \%$ & $90 \%$ & $95 \%$ & $70 \%$ & $80 \%$ & $90 \%$ & $95 \%$ \\
\hline 50 & 670 & 1660 & 3330 & 4630 & 106.7 & 97.2 & 79.9 & 72.2 \\
\hline 75 & 410 & 940 & 1610 & 2280 & 106.7 & 99.4 & 88.8 & 80.5 \\
\hline 90 & $\mathrm{NA}^{\mathrm{a}}$ & 200 & 380 & 490 & $\mathrm{NA}^{\mathrm{a}}$ & 102.5 & 97.3 & 94.8 \\
\hline 97 & $\mathrm{NA}^{\mathrm{a}}$ & $\mathrm{NA}^{\mathrm{a}}$ & $\mathrm{NA}^{\mathrm{a}}$ & $\mathrm{NA}^{\mathrm{a}}$ & $\mathrm{NA}^{\mathrm{a}}$ & $\mathrm{NA}^{\mathrm{a}}$ & $\mathrm{NA}^{\mathrm{a}}$ & $\mathrm{NA}^{\mathrm{a}}$ \\
\hline
\end{tabular}

Table 1 b. AML $=110.5$ MTU/acre.

\begin{tabular}{|c|c|c|c|c|c|c|c|c|}
\hline \multirow{2}{*}{$\begin{array}{c}\text { Repository } \\
\text { area enclosed } \\
(\%)\end{array}$} & \multicolumn{4}{|c|}{$\begin{array}{c}\text { Time to rewet to indicated } \\
\text { relative humidity (yr) }\end{array}$} & \multicolumn{4}{c|}{$\begin{array}{c}\text { Temperature when indicated } \\
\text { relative humidity is attained }\left({ }^{\circ} \mathrm{C}\right)\end{array}$} \\
\cline { 2 - 9 } & $70 \%$ & $80 \%$ & $90 \%$ & $95 \%$ & $70 \%$ & $80 \%$ & $90 \%$ & $95 \%$ \\
\hline 50 & 15,960 & 27,910 & 40,990 & 49,980 & 67.7 & 54.2 & 45.3 & 41.7 \\
\hline 75 & 9540 & 15,520 & 24,950 & 32.590 & 75.5 & 63.5 & 53.3 & 47.7 \\
\hline 90 & 3190 & 4890 & 7460 & 9890 & 93.1 & 82.0 & 73.4 & 67.9 \\
\hline 97 & 1410 & 1810 & 2360 & 2890 & 106.4 & 100.7 & 93.3 & 87.7 \\
\hline
\end{tabular}

Table 1c. $\mathrm{AML}=150.0 \mathrm{MTU} / \mathrm{acre}$.

\begin{tabular}{|c|c|c|c|c|c|c|c|c|}
\hline \multirow{2}{*}{$\begin{array}{c}\text { Repository } \\
\text { area enclosed } \\
(\%)\end{array}$} & \multicolumn{3}{|c|}{$\begin{array}{c}\text { Time to rewet to indicated } \\
\text { relative humidity }(\mathrm{yr})\end{array}$} & \multicolumn{4}{c|}{$\begin{array}{c}\text { Temperature when indicated } \\
\text { relative humidity is attained }\left({ }^{\circ} \mathrm{C}\right)\end{array}$} \\
\cline { 2 - 9 } & $70 \%$ & $80 \%$ & $90 \%$ & $95 \%$ & $70 \%$ & $80 \%$ & $90 \%$ & $95 \%$ \\
\hline 50 & 20,630 & 34,850 & 50,920 & 64,150 & 67.8 & 52.3 & 44.5 & 40.8 \\
\hline 75 & 16,400 & 24,520 & 32,700 & 43,360 & 70.1 & 59.1 & 50.9 & 46.1 \\
\hline 90 & 8660 & 12,090 & 16,520 & 19,780 & 80.9 & 72.0 & 64.1 & 59.1 \\
\hline 97 & 4330 & 6020 & 8180 & 10,060 & 92.7 & 84.3 & 76.8 & 72.2 \\
\hline
\end{tabular}

Table 1d. Nonuniform, optimized AML = 128.4 MTU/acre.

\begin{tabular}{|c|c|c|c|c|c|c|c|c|}
\hline \multirow{2}{*}{$\begin{array}{c}\text { Repository } \\
\text { area enclosed } \\
(\%)\end{array}$} & \multicolumn{4}{|c|}{$\begin{array}{c}\text { Time to rewet to indicated } \\
\text { relative humidity (yr) }\end{array}$} & \multicolumn{3}{c|}{$\begin{array}{c}\text { Temperature when indicated } \\
\text { relative humidity is attained }\left({ }^{\circ} \mathrm{C}\right)\end{array}$} \\
\cline { 2 - 9 } & $70 \%$ & $80 \%$ & $90 \%$ & $95 \%$ & $70 \%$ & $80 \%$ & $90 \%$ & $95 \%$ \\
\hline 50 & 17,860 & 32,330 & 49,080 & 61,000 & 66.9 & 50.7 & 49.2 & 38.7 \\
\hline 75 & 14,820 & 25,470 & 37,760 & 44,290 & 69.2 & 55.2 & 46.8 & 43.8 \\
\hline 90 & 10,470 & 15,280 & 21,040 & 28,070 & 75.5 & 65.8 & 57.7 & 51.2 \\
\hline 97 & 6330 & 8830 & 11,710 & 14,380 & 84.6 & 76.6 & 69.7 & 64.9 \\
\hline
\end{tabular}


during the boiling period, because $T$ and $R H$ are strongly thermodynamically controlled, $T$ and $R H$ are much less affected by hydrological variability than during the post-boiling period, particularly for high AMLs. Consequently, during the boiling period, an optimized-high-AML repository may result in uniform, reduced- $R H$ conditions, which would delay the onset of significant WP corrosion. If these observations are supported by in situ heater testing at Yucca Mountain, they will help meet the SCC requirement [7].

Although average repository conditions may remain substantially drier than ambient well beyond the end of the boiling period, rewetting to ambient $R H$ will occur nonuniformly because of hydrological variability and edge-cooling/rewetting effects. For AMLs that result in significant $R H$ reduction, repository temperatures become uniform earlier than the $R H$ distribution. For low AMLs that never significantly reduce $R H$, variations in $T$ are insufficient to cause much variability in WP corrosion rates [1]. The WP corrosion model of Stahl et al. [1] shows greater variability in WP corrosion rates for the 55.3-MTU/acre repository (which has medium rewetting times) than for the 24.2-MTU/acre repository (which has no $R H$ reduction). For $55.3 \mathrm{MTU} / \mathrm{acre}$, the variability in corrosion rate arises largely from the variability in rewetting time. This is even more the case for higher AMLs, which have longer rewetting times (Tables $1 \mathrm{~b}$ and $1 \mathrm{c}$ ). Increasing the mean rewetting time increases the range of times of onset of corrosion and (where rewetting is sufficiently delayed) leads to reduced corrosion rates associated with humid conditions. These effects increase the temporal dispersion of WP failures and thereby cause more dispersion of the source term for radionuclide transport, which would be more favorable for meeting the controlled EBS release requirement than an early narrow distribution of WP failures.

The foregoing discussion pertains largely to average repository conditions. For low to intermediate AMLs, or near the edge of a high-AML repository, conditions on the WP can be significantly hotter and drier than average conditions (compare Figs. 1 and 2). Table 3 summarizes the conditions on the WP. The repositoryscale model predicts a peak temperature $T_{\text {peak }}=66^{\circ} \mathrm{C}$ and no reduction in $R H$ for the 24.2-MTU/acre repository (Fig. 1). However, for 12-yr-old SNF, the drift-scale model predicts $T_{\text {peak }}=170^{\circ} \mathrm{C}$ on the WP (Fig. 2), and $R H$ is relatively low for hundreds of years (Table 3a). For 41-yr-old SNF, $T_{\text {peak }}$ is only $104^{\circ} \mathrm{C}$ on the WP; however, $R H$ is reduced to $43 \%$ (Fig. 2) and below-ambient $R H$ persists for thousands of years (Table 3a). To avoid boiling conditions for low AMLs, a combination of the following will be required: (1) SNF aging, (2) closely spaced drifts, (3) WPs with fewer assemblies, and (4) drift ventilation schemes.

The repository-scale model predicts $T_{\text {peak }}=110^{\circ} \mathrm{C}$ and $R H<70 \%$ for $670 \mathrm{yr}$ for the inner $50 \%$ of the 55.3-MTU/acre repository (Table 1a). However, for 12-yr-old SNF, the drift-scale model predicts $T_{\text {peak }}=180^{\circ} \mathrm{C}$ on the WP and $R H<70 \%$ for $8890 \mathrm{yr}$ (Table 3b). For 41 -yr-old SNF, $T_{\text {peak }}=112^{\circ} \mathrm{C}$ on the WP and $R H<70 \%$ for only 580 yr. In general, $T-R H$ behavior on the WP is very sensitive to SNF age for low to intermediate AMLs. For high AMLs (e.g., $110.5 \mathrm{MTU} / \mathrm{acre}$ ), this behavior is much less sensitive to SNF age (Table 3c).

\section{Thermal Management Strategies and Hypothesis Testing}

For the potential repository system at Yucca Mountain, there are two end-member thermal management strategies for avoiding the most corrosive WP conditions:

1. Minimize how long a humid repository remains hot.

2. Maximize how long a hot repository is not humid. The goal of the first strategy (sometimes called the minimally disturbed concept) is to minimize the negative

Table 2. Duration of boiling period, and relative humidity at the end of the boiling period, for 22.5-yr-old SNF.

\begin{tabular}{|c|c|c|c|c|}
\hline \multirow{2}{*}{$\begin{array}{c}\text { Repository } \\
\text { area enclosed } \\
(\%)\end{array}$} & \multicolumn{4}{|c|}{$\begin{array}{c}\text { Duration of boiling period (yr) and relative humidity (\%) } \\
\text { at end of boiling period for indicated AML }\end{array}$} \\
\cline { 2 - 5 } & $55.3 \mathrm{MTU} /$ acre & $110.5 \mathrm{MTU} /$ acre & $150.0 \mathrm{MTU} /$ acre & $128.4 \mathrm{MTU} / \mathrm{acre}^{\mathrm{a}}$ \\
\hline 50 & $1760 \mathrm{yr} 80.8 \%$ & $6130 \mathrm{yr} 44.3 \%$ & $9590 \mathrm{yr} 46.8 \%$ & $6980 \mathrm{yr} 44.3 \%$ \\
\hline 75 & $1100 \mathrm{yr} 83.7 \%$ & $4290 \mathrm{yr} 51.4 \%$ & $7210 \mathrm{yr} 45.1 \%$ & $5900 \mathrm{yr} 44.2 \%$ \\
\hline 90 & $440 \mathrm{yr} 92.7 \%$ & $2870 \mathrm{yr} 67.6 \%$ & $5010 \mathrm{yr} 54.1 \%$ & $4790 \mathrm{yr} 49.7 \%$ \\
\hline 97 & $80 \mathrm{yr} 98.5 \%$ & $2150 \mathrm{yr} 86.6 \%$ & $3960 \mathrm{yr} 66.8 \%$ & $3990 \mathrm{yr} 57.9 \%$ \\
\hline \multicolumn{5}{|c}{ Denotes a nonuniform, optimized-AML distribution. } \\
\hline
\end{tabular}


consequences of a humid repository, including the potential for heat-mobilized fluid flow. The goal of the second strategy (sometimes called the extended-dry concept) is to maximize the fraction of WPs that remain dry until they become relatively cool.

All these calculations depend on limited site data and on idealized models that have not been validated.

Hypothesis tests [3,7] help build confidence in our ability to conservatively predict performance. For the extended-dry repository, the critical questions involve how confidently we can predict the extent of above-boiling temperatures, whether such conditions correspond to a sufficient reduction in $R H$ near WPs, and how long rewetting to humid conditions lags behind the end of the boiling period. Hypothesis testing can be useful in demonstrating whether the repository system can satisfy the requirements of SCC and EBS controlled release. For the minimally disturbed repository, hypothesis testing can address whether, under sub-boiling conditions, heat-mobilized water vapor and condensate flow significantly affects
WP integrity and radionuclide dissolution and transport. The only conclusive way to address these issues is through long-term, in situ heater tests [7] and long-term monitoring of the thermo-hydrological behavior of the repository system.

\section{Conclusions}

Temperature and relative humidity are primary environmental factors affecting waste package corrosion rates at Yucca Mountain. Under ambient conditions, the repository environment is quite humid. There are two end-member thermal management strategies for avoiding the most corrosive conditions. If the high ambient relative humidity is reduced to below $70 \%$, corrosion will be minimal. For humid conditions, corrosion can be reduced if the temperature is kept below $60^{\circ} \mathrm{C}$. Thermohydrological model calculations indicate that repository heat may result in a substantial reduction in relative humidity on the waste package, with a duration of hundreds of years for low AMLs, and tens of thousands

Table 3. Time to rewet to indicated relative humidity $R H$ on WP, and WP temperature when that $R H$ is attained. See Fig. 2 for assumptions.

Table 3a. AML = 24.2 MTU/acre; 99-m drift spacing.

\begin{tabular}{|c|c|c|c|c|c|c|c|c|}
\hline \multirow{2}{*}{$\begin{array}{c}\mathrm{SNF} \\
\text { age } \\
\text { (yr) }\end{array}$} & \multicolumn{4}{|c|}{$\begin{array}{l}\text { Time to rewet to indicated } \\
\text { relative humidity }(\mathrm{yr})\end{array}$} & \multicolumn{4}{|c|}{$\begin{array}{l}\text { Temperature when indicated } \\
\text { relative humidity is attained }\left({ }^{\circ} \mathrm{C}\right)\end{array}$} \\
\hline & $60 \%$ & $70 \%$ & $80 \%$ & $90 \%$ & $60 \%$ & $70 \%$ & $80 \%$ & $90 \%$ \\
\hline 41 & 90 & 220 & 640 & 2110 & 87.5 & 77.0 & 70.0 & 54.1 \\
\hline 12 & 220 & 300 & 600 & 2320 & 116.8 & 108.7 & 101.7 & 94.8 \\
\hline \multicolumn{9}{|c|}{ Table 3b. AML = 55.3 MTU/acre; 43.4-m drift spacing. } \\
\hline \multirow{2}{*}{$\begin{array}{c}\text { SNF } \\
\text { age } \\
(\mathrm{yr})\end{array}$} & \multicolumn{4}{|c|}{$\begin{array}{l}\text { Time to rewet to indicated } \\
\text { relative humidity (yr) }\end{array}$} & \multicolumn{4}{|c|}{$\begin{array}{l}\text { Temperature when indicated } \\
\text { relative humidity is attained }\left({ }^{\circ} \mathrm{C}\right)\end{array}$} \\
\hline & $60 \%$ & $70 \%$ & $80 \%$ & $90 \%$ & $60 \%$ & $70 \%$ & $80 \%$ & $90 \%$ \\
\hline 41 & 90 & 580 & 1010 & 1550 & 110.6 & 106.5 & 101.1 & 92.3 \\
\hline 12 & 1710 & 8890 & 16,770 & 27,640 & 112.2 & 62.5 & 45.9 & 36.3 \\
\hline \multicolumn{9}{|c|}{ Table 3c. AML = 110.5 MTU/acre; 21.7-m drift spacing. } \\
\hline \multirow{2}{*}{$\begin{array}{c}\text { SNF } \\
\text { age } \\
\text { (yr) }\end{array}$} & \multicolumn{4}{|c|}{$\begin{array}{l}\text { Time to rewet to indicated } \\
\text { relative humidity }(\mathrm{yr})\end{array}$} & \multicolumn{4}{|c|}{$\begin{array}{l}\text { Temperature when indicated } \\
\text { relative humidity is attained }\left({ }^{\circ} \mathrm{C}\right)\end{array}$} \\
\hline & $50 \%$ & $60 \%$ & $70 \%$ & $80 \%$ & $50 \%$ & $60 \%$ & $70 \%$ & $80 \%$ \\
\hline 41 & 10,630 & 17,180 & 23,190 & 28,720 & 67.0 & 53.5 & 46.2 & 42.2 \\
\hline 12 & 16,090 & 20,120 & 23,110 & 26,100 & 59.8 & 53.4 & 50.5 & 47.6 \\
\hline
\end{tabular}


of years for high AMLs. Moreover, the temperatures associated with a given relative humidity decrease with increasing AML. For low to intermediate AMLs (<70 MTU/acre), temperature and relative humidity on the waste package are very sensitive to the age of the spent nuclear fuel; for high AMLs, they are much less sensitive to fuel age.

AML distributions can be optimized to yield a large, uniform reduction in relative humidity during the boiling period of a high-AML repository, thereby substantially delaying the onset of significant waste package corrosion. Although average repository conditions may continue to be much drier than ambient for tens of thousands of years after the boiling period, rewetting to humid conditions will occur nonuniformly because of hydrological variability and edge-cooling/rewetting effects. Increasing the mean rewetting time increases the range of times of onset of corrosion, and (where rewetting is sufficiently delayed) leads to reduced corrosion rates associated with humid conditions. These effects will delay the onset of radionuclide release and will contribute to greater temporal dispersion of the source term for radionuclide transport. If these observations are supported by site characterization data and in situ heater testing at Yucca Mountain, they will help demonstrate that the repository system could meet the regulatory requirements of substantially complete containment and controlled release from the engineered barrier system.

\section{Acknowledgements}

We acknowledge the review of Ken Jackson and the editorial assistance of Rick Wooten and Peter Murphy. Work performed under the auspices of the U.S. Department of Energy by Lawrence Livermore National Laboratory under Contract W-7405-Eng-48.

\section{References}

1. Stahl, D., J.K. McCoy, and R.D. McCright, "Impact of Thermal Loading on Waste Package Material Performance," Material Research Society, Pittsburgh, PA, Proceedings Material Research Society XVIII Symposium on the Scientific Basis for Nuclear Waste Management, Oct. 23-27 (1994).
2. Buscheck, T.A., J.J. Nitao, and S.F. Saterlie, "Evaluation of Thermo-Hydrological Performance in Support of the Thermal Loading Systems Study," American Nuclear Society, La Grange Park, IL, Proceedings Fifth International High-Level Radioactive Waste Management Conference, Las Vegas, NV, May 1994. Also, Lawrence Livermore National Laboratory, Livermore, CA, UCRL-JC-115352 (1994).

3. Buscheck, T.A., and J.J. Nitao, "The Impact of Buoyant Gas-Phase Flow and Heterogeneity on Thermo-Hydrological Behavior at Yucca Mountain," American Nuclear Society, La Grange Park, IL, Proceedings Fifth International High-Level Radioactive Waste Management Conference, Las Vegas, NV, May 1994. Also, Lawrence Livermore National Laboratory, Livermore, CA, UCRL-JC-115351 (1994).

4. Buscheck, T.A., and J.J. Nitao, "Repository-HeatDriven Hydrothermal Flow at Yucca Mountain, Part I: Modeling and Analysis," Nuclear Technology 104 (3), 418-448 (1993).

5. Nitao, J.J., "V-TOUGH - An Enhanced Version of the TOUGH Code for the Thermal and Hydrologic Simulation of Large-Scale Problems in Nuclear Waste Isolation," Lawrence Livermore National Laboratory, Livermore, CA, UCID-21954 (1989).

6. Pruess, K., "TOUGH User's Guide," Nuclear Regulatory Commission, Washington, DC, NUREG/CR-4645 (1987).

7. Buscheck, T.A., D.G. Wilder, and J.J. Nitao, "Repository-Heat-Driven Hydrothermal Flow at Yucca Mountain, Part II: Large-Scale In Situ Heater Tests," Nuclear Technology 104 (3), 449-471 (1993). 